Short Communication

\title{
Investigation of Hydrogen Release Rate from Electrodes of Nickel-Cadmium Batteries at Their Thermal Decomposition
}

\author{
Nikolay E. Galushkin*, Nataliya N. Yazvinskaya, Dmitriy N. Galushkin, Inna A. Galushkina \\ Don State Technical University, Laboratory of electrochemical and hydrogen energy, 147 Shevchenko \\ Street, Town of Shakhty, Rostov Region, Russia, 346500. \\ *E-mail: galushkinne@mail.ru
}

doi: $1020964 / 2018.01 .37$

Received: 3 August 2017 / Accepted: 31 October 2017 / Online Published: 1 December 2017

In this paper, kinetics is examined of a hydrogen release at thermal decomposition of oxide-nickel and cadmium electrodes of nickel-cadmium batteries KSX-25 with operating life 6 years. The examination was conducted at fixed values of temperature: $480,600,800^{\circ} \mathrm{C}$ (for cadmium electrodes) and 670,840 , $880^{\circ} \mathrm{C}$ (for oxide-nickel ones). It was proved by experiments that in electrodes of nickel-cadmium batteries in a course of their long-lasting operation, a great amount of hydrogen is accumulated. The rate of the hydrogen release and the released hydrogen amount grow with decomposition temperature increase. Although at temperatures higher than $900^{\circ} \mathrm{C}$, the released hydrogen volume does not grow any longer. This fact shows that hydrogen atoms are contained inside of ceramic-metal matrix of electrodes in a potential hole, i.e. in their bound state. Energy values were found of hydrogen atoms activation for diffusion process in ceramic-metal matrices of oxide-nickel and cadmium electrodes; they are equal to $0.37 \mathrm{eV}$ and $0.34 \mathrm{eV}$ respectively.

Keywords: battery, nickel-cadmium, hydrogen accumulation, thermal runaway.

\section{FULL TEXT}

(C) 2018 The Authors. Published by ESG (www.electrochemsci.org). This article is an open access article distributed under the terms and conditions of the Creative Commons Attribution license (http://creativecommons.org/licenses/by/4.0/). 